УДК 378.14

https://doi.org/10.33296/2707-0255-9(17)-14

https://orcid.org/0000-0003-2392-3417

\author{
МАЦАПУРА ТАРАС \\ аспірант кафедри педагогіки, \\ професійної освіти та управління \\ освітніми закладами \\ Житомирського державного університету \\ імені Івана Франка \\ Житомир
}

\title{
ОСНОВНІ ЗАВДАННЯ ПРОЦЕСУ УПРАВЛІННЯ МАРКЕТИНГОМ У ЗАКЛАДАХ ОСВІТИ
}

Анотація. На сучасному етапі розвитку освітнього простору загострюється проблема діяльності закладів освіти як суб'єктів ринкових відносин та виробників освітніх послуг. Важливою $є$ розробка й застосування в системі управління закладів освіти таких механізмів, реалізація яких забезпечить урахування державної політики в галузі освіти та сучасних економічних факторів впливу на іiі розвиток в існуючих ринкових умовах.. У статті представлено та проаналізовано особливості основних завдань процесу управління маркетингом у закладах освіти. Висвітлено специфічні риси сфери освіти, що обумовлюють особливості завдань процесу управління маркетингом у закладах освіти. Також аналізуються важливі на сьогоднішній день завдання, необхідні для реалізації процесу управління маркетингом у закладах освіти. Визначено ефективні шляхи виконання завдань процесу управління маркетингом у закладах освіти. Зазначається певна вивченість питання, подаються прізвища науковців, які розкривали сутність освітнього маркетингу, надання освітніх послуг i проведення маркетингових досліджень. Наголошується на недостатній розробленості досліджуваної проблеми i необхідності формулювання та вдосконалення основних завдань процесу управління маркетингом у закладах освіти.

В основній частині статті йдеться про завдання процесу управління маркетингом у закладах освіти, надання освітніх послуг та структурні елементи управління маркетингом. Розкривається сутність процесу управління маркетингом у закладах освіти. Саме управління маркетингом є діяльністю, яка має на меті якомога вигідніше представити заклад освіти на ринку освітніх послуг. Особлива увага в статті приділяється шляхам ведення маркетингової політики у закладі освіти. Зазначається, що виконання основних завдань

\footnotetext{
(C) Украӥнська інженерно-педагогічна академія

(C) ГО «Школа адаптивного управління соціально-педагогічними системами»

(C) Maцanypa T.
} 
процесу управління маркетингом у закладах освіти забезпечить вигідне i конкурентоспроможне становище на ринку освітніх послуг.

Ключові слова: управління маркетингом, заклад освіти, автоматизація маркетингу, прибуток, ринок освітніх послуг, структурні елементи управління маркетингом, комунікаційні технологіі, інформація, глобалізація.

\section{Постановка проблеми у загальному вигляді та її зв'язок із} важливими практичними завданнями. Реалії сучасного інформаційного світу, процеси діджиталізації, динамічність змін у навколишньому середовищі, мінливість потреб споживачів, пандемія коронавірусної хвороби у світі, запровадження карантинних заходів, а також процес формування загальноєвропейського освітнього простору зумовлюють необхідність реформування освіти і використання сучасних маркетингових підходів 3 метою підвищення ефективності іiі діяльності.

Аналіз останніх досліджень і публікацій. Теоретико-методологічні засади визначення сутності освітнього маркетингу грунтуються на класичних роботах таких зарубіжних дослідників, як Г. Армстронг, Б. Берман, В. Вонг, П. Друкер, Дж. Еванс, Ф. Котлер, Р. Моррис, Ф. Махлуп, Е. Райс, Дж. Сондерс, Дж. Траут, К. Фокс та ін.

Надання освітніх послуг і проведення маркетингових досліджень в освіті розглядалися у працях Б. Братаніча, М. Волкової, Т. Гайдаєнка, Н. Галєтової, Є. Голубкова, С. Захаренкова, А. Звєздової, С. Ілляшенка, М. Карпіщенко, С. Катасонова, Ф. Котлера, Н. Літвінової, Г. Міщенка, I. Мороза, Т. Оболенської, . Панкрухіна, С. Подшибякіної, 3. Рябової, Т. Сорочан, П. Третьякова, М. Тубєрозової, К. Фокс, Н. Шарай, Л. Шемятіхіної, В. Шереметової та ін.

На основі аналізу наукових праць багатьох авторів можна зазначити, що в умовах сьогодення для забезпечення конкурентоспроможності закладу освіти необхідно забезпечити якість надання освітніх послуг на основі вивчення попиту споживачів, враховуючи непрості умови, що склалися останнім часом на ринку освітніх послуг. Тобто загальним результатом аналізу наукових праць 
Електронне наукове фахове видання «Адаптивне управління: теорія і практика. Серія «Педагогіка»

$\epsilon$ висновок про доцільність i необхідність використання маркетингових досліджень в управлінській діяльності, що забезпечує узгодження сучасних вимог педагогічної теорії та практики й потреб споживачів освітніх послуг.

Мета статті - теоретично обгрунтувати основні завдання процесу управління маркетингом у закладах освіти.

Виклад основного матеріалу. Управління закладом освіти як цілісна діяльність керівника включає в себе управління різними аспектами його діяльності. Управління маркетингом являє собою складний процес, що охоплює функції, пов'язані з ринком освітніх послуг, потребами споживачів, доставкою товарів, безпосередньо надання освітніх послуг, ціновою політикою, комунікацію з клієнтами тощо. Управління маркетингом передбачає вивчення потреб покупців, розподіл ринку на сегменти, виявлення найбільш перспективних із них, створення відповідно до цих сегментів окремих товарів та послуг [6].

Об’єктами маркетингу в системі освіти водночас з освітніми послугами є місця розташування закладів освіти, їх навчально-матеріальна база, громадський престиж і привабливість професій чи спеціальностей серед різних груп населення, рейтинг викладачів, рівень наукових досліджень у закладах освіти, навчально-методичне забезпечення навчального процесу, широкий комплекс супутніх послуг.

Управління маркетингом $€$ організованим процесом здійснення опрацьованих планів і інших маркетингових ідей в реальних умовах діяльності закладу освіти. Управління маркетингом розуміється як процес прийняття рішень стосовно діяльності закладу освіти на ринку освітніх послуг. Він включає в себе: планування, організацію, здійснення на практиці та контроль за проведенням заходів, розрахованих на встановлення, зміцнення та підтримку вигідних обмінів 3 цільовими споживачами 3 певною метою (одержання прибутку, зростання обсягів збуту, розширення частки ринку тощо). Процес управління маркетингом - це аналіз ринкових можливостей, добору цільових 
Електронне наукове фахове видання «Адаптивне управління: теорія і практика. Серія «Педагогіка»

ринків, розробки комплексу маркетингу і перетворення в життя маркетингових заходів $[2 ; 4 ; 9]$.

До основних завдань процесу управління маркетингом у закладах освіти належать:

- формування цілей та визначення шляхів їх досягнення:

○ повернення капіталовкладень;

○ одержання прибутку;

○ збільшення частки закладу освіти на ринку освітніх послуг;

○ упровадження у діяльність нових освітніх послуг тощо;

- формування організаційної структури маркетингу, визначення повноважень, відповідальності працівників за реалізацію маркетингових заходів;

• аналіз ринку, попиту, конкуренції, поведінки споживачів тощо;

- розробка і реалізація маркетингових програм щодо створення та освоєння нових засобів надання освітніх послуг;

- підготовка планів закупівель матеріально-технічних ресурсів;

- формування плану дій;

- визначення відповідних стимулів (моральних та матеріальних) для працівників, щоб досягти поставлених цілей [3; 4; 9].

Для кращого розуміння сутності, цілісності та доцільності завдань процесу управління маркетингом у закладах освіти необхідно охарактеризувати основні структурні елементи управління маркетингом (табл.1).

До основних інструментів системи просування на ринку освітніх послуг належать: реклама як будьяка оплачена форма неособистого представлення i просування освітніх послуг чітко визначеним рекламодавцем; стимулювання збуту як система короткочасних спонукальних заходів і прийомів заохочення покупки або продажу освітньої послуги; персональні продажі як усне уявлення освітніх послуг під час бесіди з одним або декількома потенційними покупцями з метою здійснення їх продажу; зв’язки з громадськістю як заплановані тривалі 
Електронне наукове фахове видання «Адаптивне управління: теорія і практика. Серія «Педагогіка»

зусилля, спрямовані на створення і підтримку відносин освітнього закладу 3 різними верствами громадськості.

Таблиця 1

Структурні елементи управління маркетингом

\begin{tabular}{|c|c|}
\hline $\begin{array}{c}\text { Структурний } \\
\text { елемент }\end{array}$ & Включас \\
\hline Планування & Прогнозування; аналіз ситуації; встановлення мети; \\
& визначення напрямку і способів діяльності. \\
\hline Організація & Побудова структур, які будуть реалізовувати план. \\
\hline Реалізація & Розподіл завдань; координація та мотивація здійснення \\
& цілей. \\
\hline Контроль & Вимір просування в досягненні цілей; перевірка стратегії \\
& і тактик. \\
\hline
\end{tabular}

Одним 3 важливих чинників маркетингу освітніх послуг є маркетингові комунікації. До системи комунікацій у маркетингу належать засоби і процеси надання споживачу інформації про ринок і пропоновану послугу. Традиційно в комплекс таких комунікацій входять реклама; бренд установи, громадська думка про заснування, про якість послуг, про працевлаштування, особисті контакти. У даний час маркетингові комунікації у сфері застосування інформаційних технологій широко трансформуються в інтегровані маркетингові комунікації - це концепція спільного використання всіх видів маркетингових комунікацій, виходячи з головних цілей. Окремі комунікації при цьому доповнюють одна одну, що створює синергетичний ефект, який підвищує якість маркетингових освітніх послуг.

Сьогодні маркетинг освіти розвивається дуже інтенсивно і відіграє двояку роль в сучасній економіці. Це пов’язано, насамперед, з особливою значущістю освіти в економічному розвитку. Сучасні технології забезпечують високий рівень i якість життя в розвинених країнах та задають верхню межу
(C) Украӥнська інженерно-педагогічна академія
(С) ГО «Школа адаптивного управління соціально-педагогічними системами»
(C) Maцanypa T. 
Електронне наукове фахове видання «Адаптивне управління: теорія і практика. Серія «Педагогіка»

економічного зростання, темпи якого, з досвіду нових індустріальних країн, можуть бути дуже великі. Нові технології доступні всім, проте поширення їх залежить від системи і рівня освіти населення.

Таким чином, маркетинг освіти пов’язаний 3 поширенням ідеї освіти та потребує розробки відповідної стратегії. Говорячи про стратегію маркетингової діяльності вищого навчального закладу, відзначимо, що вона включає аналіз можливостей і загроз ринку, конкурентів, сильних і слабких сторін і на основі такого аналізу формулює власні конкурентні переваги. Стратегія маркетингу освітніх послуг повинна включати: конкретні цілі та завдання ВНЗ, опис його цільових аудиторій і споживачів, опис процедур, конкурентних переваг освітніх програм навчального закладу, з якими він виходить на ринок. Дані положення стратегії маркетингу вищої освіти мають розроблятися на достатньому рівні i бути готовими до практичного їх використання в поточній діяльності закладу освіти.

Для ефективного його просування необхідно використовувати різні комунікаційні технології, об'єднуючи їх у систему продуманих стратегічно вибудуваних дій. Кожна комунікаційна технологія, будь то реклама або зв’язки з громадськістю, прямий маркетинг або ярмаркова і виставкова діяльність, має свої особливості впливу на споживачів. Об'єднання різних комунікаційних технологій у систему інтегрованих маркетингових комунікацій дозволяє посилити ефективність кожної з них i, звичайно ж, загальну результативність [6]. Ці дії в першу чергу повинні бути спрямовані на створення позитивного іміджу ВНЗ і таким чином вивести його на новий рівень на ринку освітніх послуг.

Для цього необхідно визначити шляхи ведення маркетингової політики вузу, головним з яких має стати налагодження зв'язків з громадськістю. Це, в першу чергу, потрібно для виховання громадської думки: освітній заклад має всилити споживачеві дійсність його локальної ідеї та зробити все можливе для того, щоб існування освітнього закладу стало цікавим споживачеві.

\footnotetext{
(C) Украйнська інженерно-педагогічна академія

(C) ГО «Школа адаптивного управління соціально-педагогічними системами»

(C) Maцanypa T.
} 
Основна мета формування громадської думки - створити міцну позицію освітнього закладу в суспільстві і на потенційних ринках. Технологічна схема дії механізму формування громадської думки - це ланцюжок послідовних дій: заявити про себе - залучити і утримувати увагу - викликати інтерес - зняти напруженість і недовіру - сформувати позитивний імідж - ініціювати бажання - спонукати суспільство до бажаної для освітнього закладу дії удосконалювати імідж установи (підвищувати рейтинг) [7]. Вибір напряму просування освітніх послуг формується споживачем, адже саме довкола нього відбувається організація маркетингової пропозиції у сфері освіти.

Враховуючи той факт, що в сучасному суспільстві наростають тенденції глобалізації суспільного життя, які стосуються і освіти, намітилася інтеграція освітніх структур і просторів на всіх рівнях. У вітчизняних вищих навчальних закладах отримала своє поширення Болонська система, яка являє собою застосування дворівневої системи вищої освіти: бакалаврату та магістратури.

Проте, існують перешкоди, що заважають навчатися при традиційній системі освіти, основними з яких є:

- необхідність поєднувати навчання з основною діяльністю;

- обмежена пропускна здатність традиційної системи освіти та пов'язані 3 нею необхідність проходження конкурсного відбору, корупція i зловживання в освітніх установах, невпевненість у своїй здатності подолати конкурсний бар’єр тощо;

- неможливість регулярно відвідувати навчальний заклад за рахунок його віддаленості, великі витрати на переїзд та проживання або обмежені можливості через стан здоров'я;

- недоступно висока плата за навчання тощо.

Незважаючи на представлені переваги, нові технології навчання потребують детального вивчення та апробації, проте необхідною умовою їх розвитку також залишається поширення інформації про них у суспільстві. У такому випадку очікуваним буде посилення маркетингової системи управління 
Електронне наукове фахове видання «Адаптивне управління: теорія і практика. Серія «Педагогіка»

освітніми послугами та їх якістю, включаючи рекламу, канали розподілу, забезпечення конкуренції та дослідження ринку. Це дає можливість стверджувати, що: для успішного управління освітою та отримання доходів від зростання освітніх послуг необхідно створити певну модель, яка буде описувати процеси взаємодії викладачів і студентів у навчальній діяльності. Вона має визначати взаємозалежність і взаємозв'язок між зростанням доходів освітньої установи, задоволеністю викладачів і співробітників роботою у вищому навчальному закладі, цінністю освітніх послуг, які пропонуються студентам, і зростанням матеріальних і нематеріальних активів. Для створення окремого освітнього продукту i забезпечення його конкурентоспроможності необхідний не тільки маркетинговий підхід, а й організаційний, економічний $\mathrm{i}$ управлінський підходи.

Проведення конкурентного аналізу слід розглядати як початкові дії при освоєнні ринкового підходу вищим навчальним закладом. Крім того, необхідна робота з планування та прогнозування запитів різних цільових аудиторій, позиціонування вищого навчального закладу і послуг, з якими він виходить на ринок, управління їх конкурентоспроможністю, розробки маркетингових стратегій, дослідження поведінки на різних ринкових сегментах, зміцненню іміджу вищого навчального закладу, формування його бренду, розробки його цілей, моніторингу персоналу і т.д.

У рамках вищого навчального закладу доцільним було б створення спеціальної служби, що зможе вирішувати наступні завдання: стратегічне планування, з метою постійного підвищення якості існуючих освітніх послуг; аналіз економічної діяльності освітньої установи; менеджмент якості; розвиток рекламної політики навчального закладу; проведення маркетингових досліджень у освітній сфері та ін. Таким чином, маркетинг вищого навчального закладу - необхідна і важлива частина його діяльності.

Висновки і перспективи щодо подальших досліджень. Отже, процес управління маркетингом у закладах освіти має визначені завдання, які
(C) Украйнська інженерно-педагогічна академія
(C) ГО «Школа адаптивного управління соціально-педагогічними системами»
(C) Maцanypa T. 
Електронне наукове фахове видання «Адаптивне управління: теорія і практика. Серія «Педагогіка»

включають в себе розроблення, реалізацію й оцінювання освітніх послуг через установлення відносин обміну між закладами освіти та споживачами освітніх послуг з метою гармонізації інтересів і задоволення потреб школярів, учнів, студентів і слухачів. Маркетинг освітніх послуг допомагає кожному закладу освіти посісти своє місце на ринку освітніх послуг, здійснювати підготовку кадрів відповідно до потреб ринку праці й завдяки цьому підвищити власний рівень конкурентоспроможності.

Сьогодні процес управління маркетингом у закладах освіти розвивається дуже інтенсивно і відіграє двояку роль в сучасній економіці. Це пов'язано, насамперед, з особливою значущістю освіти в економічному розвитку. Сучасні технології забезпечують високий рівень і якість життя в розвинених країнах та задають верхню межу економічного зростання, темпи якого, 3 досвіду нових індустріальних країн, можуть бути надто великі. Нові технології доступні всім, проте поширення їх залежить від системи і рівня освіти населення.

Виходячи $з$ цього можна з упевненістю стверджувати, що заклади освіти, які не приділяють належної уваги маркетинговій діяльності, вже найближчим часом можуть опинитися в невигідному та неконкурентоспроможному становищі на ринку освітніх послуг і врешті припинити своє існування.

На завершення підкреслимо, що в сучасному світі знань зростає усвідомлення того, що без здійснення сформульованих вище завдань процесу управління маркетингом у закладах освіти, як і без забезпечення відповідною фінансовою підтримкою закладів освіти, сучасна освіта не в змозі виконати свою місію підготовки молоді в конкурентоспроможних умовах, в умовах розвитку економіки знань. Таке усвідомлення породжує значну кількість практичних кроків щодо втілення нової технології створення стратегічних альянсів між освітніми установами і бізнесовими структурами, що становлять значний дослідницький інтерес, вартий подальшого вивчення. 


\section{Використані джерела:}

1. Бобало О.Ю. Вітчизняний досвід маркетингової діяльності вищих навчальних закладів. Пропозиції щодо використання маркетингових інструментів [Електронний ресурс] / О.Ю. Бобало // Науковий вісник. - 2011. - Вип. 8. - Режим доступу: http://www.lvivacademy.com/visnik8/fail/Bobalo.pdf

2. Гончаренко C.I. Позиціонування загальноосвітнього навчального закладу на ринку освітніх послуг / C.I. Гончаренко [Електронний ресурс]. Режим доступу: http://umo.edu.ua/images/content/nashi vydanya/stud almanah/ v_1/11.pdf

3. Зозульов О.В. Типи позиціонування товарів і марок на споживчому ринку / О.В. Зозульов // Маркетинг в Україні. - 2008. - №6. - С. 49-52.

4. Котлер Ф. Основы маркетинга / Ф. Котлер ; пер. с англ. - М. : Бизнес-книга, ИМА-Кросс. Плюс, 1995. - 702 с.

5. Кунанець О., Дідух Г. Досвід залучення дітей з особливими потребами до загальноосвітніх шкіл // Психолог. - 2004. - № 37. - С.18-21.

6. Лапыгин Д.Ю. Методическое обеспечение процесса разработки плана стратегического развития региона / Д.Ю. Лапыгин // Менеджмент в России и за рубежом. - 2005. - № 6. - С. 40-52

7. Липчук В. В. Маркетинг: навч. пос. / В. В. Липчук, Р. П. Дудяк, С. Я. Бугіль, Я. С. Янишин. - Львів: „Магнолія 2006”, 2012. - 456 с.;

8. Маркетинговий менеджмент : навч. посіб. / С. В. Крикавський, I. О. Дейнега, О. В. Дейнега, І. Ф. Лорві; Нац. ун-т "Львів. політехніка". - Львів : Вид-во Львів. політехніки, 2014. - 379 с. - (Серія "Світ маркетингу і логістики"; вип. 8). - Бібліогр.: с. 374-375;

9. Петруня Ю.С. Маркетинг на ринку освітніх послуг / Ю. Петруня, М. Залесов, В. Брижатий // Вісник ТАНГ. - 2003. - №5. - С.163-167.

10.Ткаченко О.О. Сутність та особливості позиціонування вищих навчальних закладів / O.О. Ткаченко [Електронний ресурс].

Режим доступу: file:///C:/Users/Lenovo/Downloads/bdi_2015_2_13.pdf 
11.Траут Дж. Позиционирование. Битва за узнаваемость / Дж. Траут, Э. Райс ;

пер. с англ. С. Жильцова. - СПб. : Питер, 2004. - 256 с.

\section{Reference}

1.Bobalo O.Iu. Vitchyznianyi docvid marketynhovoi diialnocti vyshchyx navchalnyx zakladiv. Propozytsii shchodo vykoryctannia marketynhovyx inctrumentiv [Elektronnyi recurc] / O.Iu. Bobalo // Naukovyi vicnyk. - 2011. - Vyp. 8. - Rezhym doctupu: http://www.lvivacademu.com/visnik8/fail/Bobalo.pdf

2.Honcharenko C.I. Pozytsionuvannia zahalnoocvitnoho navchalnoho zakladu na rynku ocvitnix pocluh / C.I. Honcharenko [Elektronnyi recurc]. - Rezhym doctupu: http://umo.edu.ua/images/content/nashi_vudanua/stud_almanah/v_1/11.pdf 3.Zozulov O.V. Typy pozytsionuvannia tovariv i marok na cpozhyvchomu rynku / O.V. Zozulov // Marketynh v Ukraini. - 2008. - №6. - C. 49-52.

4.Kotler F. Ocnovu marketynha / F. Kotler ; per. c anhl. - M. : Byznec-knyha, YMAKrocc. Pliuc, 1995. - 702 c.

5.Kunanets O., Didux H. Docvid zaluchennia ditei z ocoblyvymy potrebamy do zahalnoocvitnix shkil // Pcyxoloh. - 2004. - № 37. - C.18-21.

6.Lapyhyn D.Iu. Metodycheckoe obecpechenye protsecca razrabotky plana ctratehycheckoho razvytyia rehyona / D.Iu. Lapыhyn // Menedzhment v Roccyy y za rubezhom. -2005 . - № 6. - C. 40-52

7.Lypchuk V. V. Marketynh: navch. poc. / V. V. Lypchuk, R. P. Dudiak, C. Ya. Buhil, Ya. C. Yanyshyn. - Lviv: „Mahnoliia 2006”, 2012. - 456 c.;

8.Marketynhovyi menedzhment : navch. pocib. / Ye. V. Krykavckyi, I. O. Deineha, O. V. Deineha, I. F. Lorvi; Nats. un-t "Lviv. politexnika". - Lviv : Vyd-vo Lviv. politexniky, 2014. - 379 c. - (Ceriia "Cvit marketynhu i lohictyky"; vyp. 8). Bibliohr.: c. 374-375;

9.Petrunia Yu.Ie. Marketynh na rynku ocvitnix pocluh / Yu. Petrunia, M. Zalecov, V. Bryzhatyi // Vicnyk TANH. - 2003. - №5. - C.163-167.

10.Tkachenko O.O. Cutnict ta ocoblyvocti pozytsionuvannia vyshchyx navchalnyx zakladiv / O.O. Tkachenko [Elektronnyi recurc]. - Rezhym doctupu:

file:///C:/Users/Lenovo/Downloads/bdi_2015_2_13.pdf

11.Traut Dzh. Pozytsyonyrovanye. Bytva za uznavaemoct / Dzh. Traut, Э. Raic ; per. c anhl. C. Zhyltsova. - CPb. : Pyter, 2004. - 256 c.

МАЦАПУРА ТАРАС. аспирант кафедры педагогики, профессиональное образование и управление образовательными учреждениями Житомирский государственный университет имени Ивана Франко Житомир 


\section{ОСНОВНЫЕ ЗАДАЧИ ПРОЦЕССА МАРКЕТИНГОВОГО УПРАВЛЕНИЯ В ОБРАЗОВАТЕЛЬНЫХ УЧРЕЖДЕНИЯХ}

На современном этапе развития образовательного пространства обостряется проблема деятельности образовательных учреждений как субъектов рыночных отношений и производителей образовательных услуг. Важно разработать и применить такие механизмы в системе управления образовательными учреждениями, реализация которых обеспечит учет государственной политики в сфере образования и современных экономических факторов влияния на это развитие в существующих рыночных условиях. . В статье представлены и проанализированы основные задачи процесса управления маркетингом в образовательных учреждениях. Выделены специфические критерии сферы образования, определяющие особенности задач процесса управления маркетингом в образовательных учреждениях. Также мы анализируем важные на сегодня задачи, которые необходимы для внедрения процесса управления маркетингом в образовательных учреждениях. Определены эффективные способы решения задач процесса управления маркетингом в образовательных учреждениях. Отмечается определенная проработка вопроса, приводятся имена ученых, раскрывающих сущность образовательного маркетинга, оказания образовательных услуг и маркетинговых исследований. Отмечается недостаточная проработка изучаемой проблемы и необходимость формулирования и совершенствования основных задач процесса управления маркетингом в образовательных учреждениях. Основная часть статьи посвящена задачам управления маркетингом в образовательных учреждениях, оказанию образовательных услуг и структурным элементам управления маркетингом. Раскрыта сущность процесса управления маркетингом в образовательных учреждениях. Это менеджмент. Маркетинг - 
это специальность, по которой необходимо максимально выгодно

представить учебное заведение на рынке образовательных услуг. Особое внимание уделяется способам проведения маркетинговой политики в образовательном учреждении. Отмечается, что выполнение основных задач процесса управления маркетингом в образовательных учреждениях обеспечит выгодную и конкурентоспособную позицию на рынке образовательных услуг.

Ключевые слова: управление маркетингом, учебное заведение, автоматизация маркетинга, прибыль, рынок образовательных услуг, структурные элементы управления маркетингом, коммуникационные технологии, информация, глобализация.

\section{MATSAPURA TARAS.}

graduate student of the Department of Pedagogy, vocational education and management of educational institutions Ivan Franko Zhytomyr State University Zhytomyr

\section{THE MAIN OBJECTIVES OF THE MARKETING MANAGEMENT PROCESS IN EDUCATIONAL INSTITUTIONS}

At the present stage of development of the educational space, the problem of the activities of educational institutions as subjects of market relations and producers of educational services is becoming more acute. It is important to develop and apply such mechanisms in the management system of educational institutions, the implementation of which will ensure that the state policy in the field of education and modern economic factors of influence on this development in the existing market conditions are taken into account. The article introduces and analyzes the main tasks of the marketing management process in educational institutions. The specific criteria of the sphere of education are highlighted, which determine the characteristics of the tasks of the marketing management process in educational institutions. We also analyze the important tasks for today, which are necessary for the implementation of the marketing management process in educational institutions. The effective ways of fulfilling the tasks of the marketing management process in educational institutions have been determined. A certain study of the issue is noted, the names of scientists

\footnotetext{
(C) Украйнська інженерно-педагогічна академія

(C) ГО «Школа адаптивного управління соціально-педагогічними системами»

(C) Maцanypa T.
} 
who reveal the essence of educational marketing, the provision of educational services and marketing research are given. Insufficient development of the problem under study and the need to formulate and improve the main tasks of the marketing management process in educational institutions are noted. The main part of the article deals with the tasks of the marketing management process in educational institutions, the provision of educational services and the structural elements of marketing management. The essence of the process of marketing management in educational institutions is revealed. It is management Marketing is a specialty, which should be as profitable as possible to present an educational institution on the market of educational services. Particular attention is paid to the ways of conducting marketing policy in an educational institution. It is noted that the fulfillment of the main tasks of the marketing management process in educational institutions will provide an advantageous and competitive position in the educational services market.

Keywords: marketing management, educational institution, marketing automation, profit, educational services market, structural elements of marketing management, communication technologies, information, globalization. 